Possibilities of identifying cyber attack in noisy space of $n$-dimensional abstract system

Roman Jašek, Jiří Dvořák, Martina Janková, and Michal Sedláček

Citation: AIP Conference Proceedings 1738, 120017 (2016); doi: 10.1063/1.4951900

View online: http://dx.doi.org/10.1063/1.4951900

View Table of Contents: http://aip.scitation.org/toc/apc/1738/1

Published by the American Institute of Physics 


\title{
Possibilities of Identifying Cyber Attack in Noisy Space of N- Dimensional Abstract System
}

\author{
Roman Jašek, Jiří Dvořák, Martina Janková and Michal Sedláček \\ Tomas Bata University in Zlin \\ Nad Stranemi 4511, 76005 Zlin, Czech republic \\ jasek@fai.utb.cz,dvorakj@aconte.cz,martina.jankova@email.cz,michal.sedlacek@email.cz
}

\begin{abstract}
This article briefly mentions some selected options of current concept for identifying cyber attacks from the perspective of the new cyberspace of real system. In the cyberspace, there is defined n-dimensional abstract system containing elements of the spatial arrangement of partial system elements such as micro-environment of cyber systems surrounded by other suitably arranged corresponding noise space. This space is also gradually supplemented by a new image of dynamic processes in a discreet environment, and corresponding again to n-dimensional expression of time space defining existence and also the prediction for expected cyber attacksin the noise space. Noises are seen here as useful and necessary for modern information and communication technologies (e.g. in processes of applied cryptography in ICT) and then the so-called useless noises designed for initial (necessary) filtering of this highly aggressive environment and in future expectedly offensive background in cyber war (e.g. the destruction of unmanned means of an electromagnetic pulse, or for destruction of new safety barriers created on principles of electrostatic field or on other principles of modern physics, etc.).The key to these new options is the expression of abstract systems based on the models of microelements of cyber systems and their hierarchical concept in structure of n-dimensional system in given cyberspace. The aim of this article is to highlight the possible systemic expression of cyberspace of abstract system and possible identification in time-spatial expression of real environment (on microelements of cyber systems and their surroundings with noise characteristics and time dimension in dynamic of microelements' own time and externaltime defined by real environment). The article was based on a partial task of faculty specific research.
\end{abstract}

Keywords: Applied cybernetics, system modelling, cyber attacks, noise space, cyberspace, simulated modeling. PACS: 07,05. Tp

\section{INTRODUCTION}

Efforts for a description of the cyber attacks in modern information and communication technologies (ICT) and their applications in practice on the Internet and also in a large number of user applications on computer networks in electronic business, commerce, banking, government and public administration, etc. lead a number of major research centres in the world to work on collecting information about possible cyber attacks and their identification.

Published experience and their importance to the war zone can be gradually used for numerous areas of civil sector and thus express in the field of technical and social systems new system-defined space in the development of applied cybernetics for the purposes of economic cybernetics towards a new conception of ICT in the new knowledge economy of the civilized world.

An important part of the research methodology is theoretical and applied cybernetics. Essence of partial directions in solving specific research faculty is shown in (Fig.1).

\section{LITERATURE REVIEW}

Modelling undertaken on the gradually developed model M - by suitable programming language on PC - allows to create by a new method of simulation modelling (Fig.2 and Fig.3) adaptable model of system S. The creation of the model $\mathrm{M}$ in purpose-defined environments and modelling environments is generally described in numerous publications and articles [1], [7] which is filled with erudite view amidst into a broader philosophical, psycho-social, economic and educational contexts embedded in European and world context with effectively linked control variables related mainly to social environment [2], [8] Modern possibilities of advanced artificial intelligence methods in integrative environment of cybernetics, [5], [6] describes the modern means of technical cybernetics and their modelling for system integration [3], [10] in the cyber environment [4], [9]. 


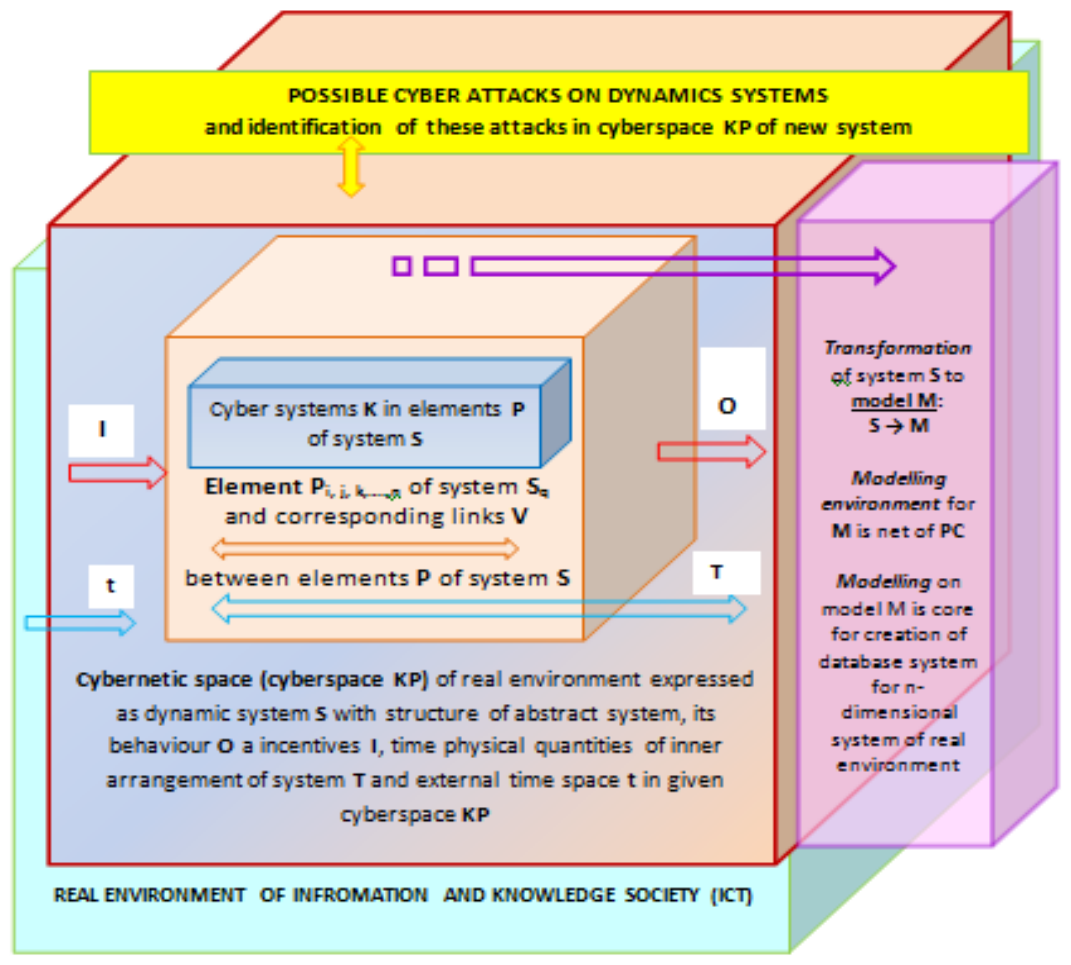

FIGURE 1. System definition of cyberspace for expressing environment of research tasks.

\section{RESULTS AND DISCUSSION}

\section{A. The Research's Systemic Definition}

The solution basis of faculty specific research is systemic definition of new issue "Possibilities of Identifying Cyber Attack in Noisy Space of N-Dimensional Abstract System" and comprehensive approach to systemic expression in cyberspace by Fig. 1.

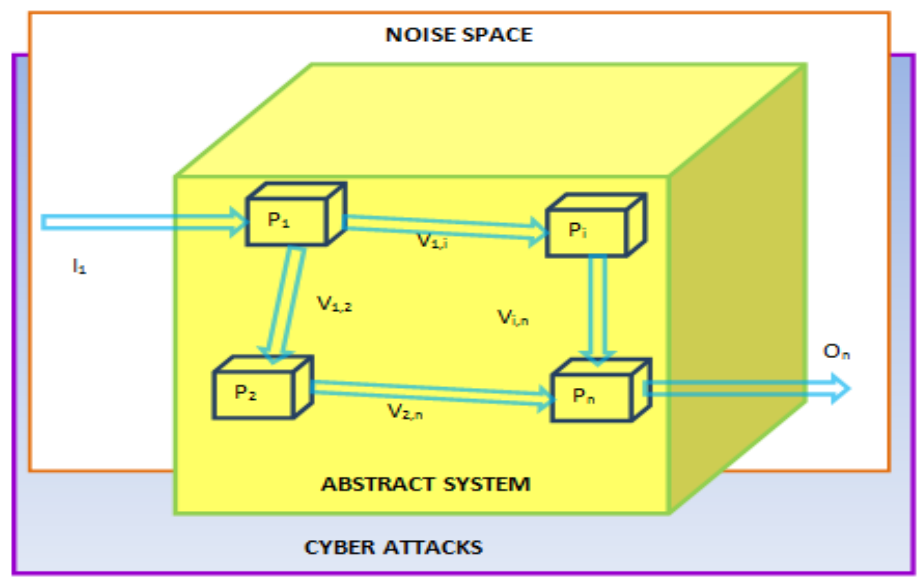

FIGURE 2. System definition of solved problems of specific research. 
The fundamental approach is to use options of proven "Systems Theory" (Bartalanfy, 1923) as the main tool for the design of future model of the real environment of system-defined research (Fig.2). The figure highlights identifiable (analyzed, recognizable) environment of abstractly conceived (general) system and its near surroundings expressed with incentives (inputs) $\mathrm{I}_{1}$, behaviour (reaction) $\mathrm{O}_{\mathrm{n}}$ andimportant noise space, in which closenesscyber attacks are possible.

\section{B. Model Creation and a Newly Conceived Simulation Method for System Modelling}

The model creation of given transformation of the system $\mathrm{S}$ to model M (Fig. 1) is implemented by:

- creation of database for n-dimensional abstract system:

matrix of system elements expressing modules of elementary cybernetic systems according to Fig. 1. Each of these sub-matrixes form the core of the "cell" similar to the cellular structure of living organisms,

flanging of the cell matrix is constructed as a "permeable and controlled" membrane ensuring contact with the immediate surroundings,

another layer of the matrix are time internal and external parameters necessary for the description of the dynamics of the entire system and also for created modular sequences of model $\mathrm{M}$,

in the other parts are defined means for rescue and liquidation environment against identifiedattacks in noisy environments and it is represented by diagnostic matrix (similar to the protocols of antivirus processes in ICT).

- constructionof simulator for modelling:

major point of the research is to design a cybernetic process in the simulator for modelling of adaptive program in the process of innovative steps leading towards applications training and learning of these future systems

briefly expressed an adaptable process is shown in Fig. 3.

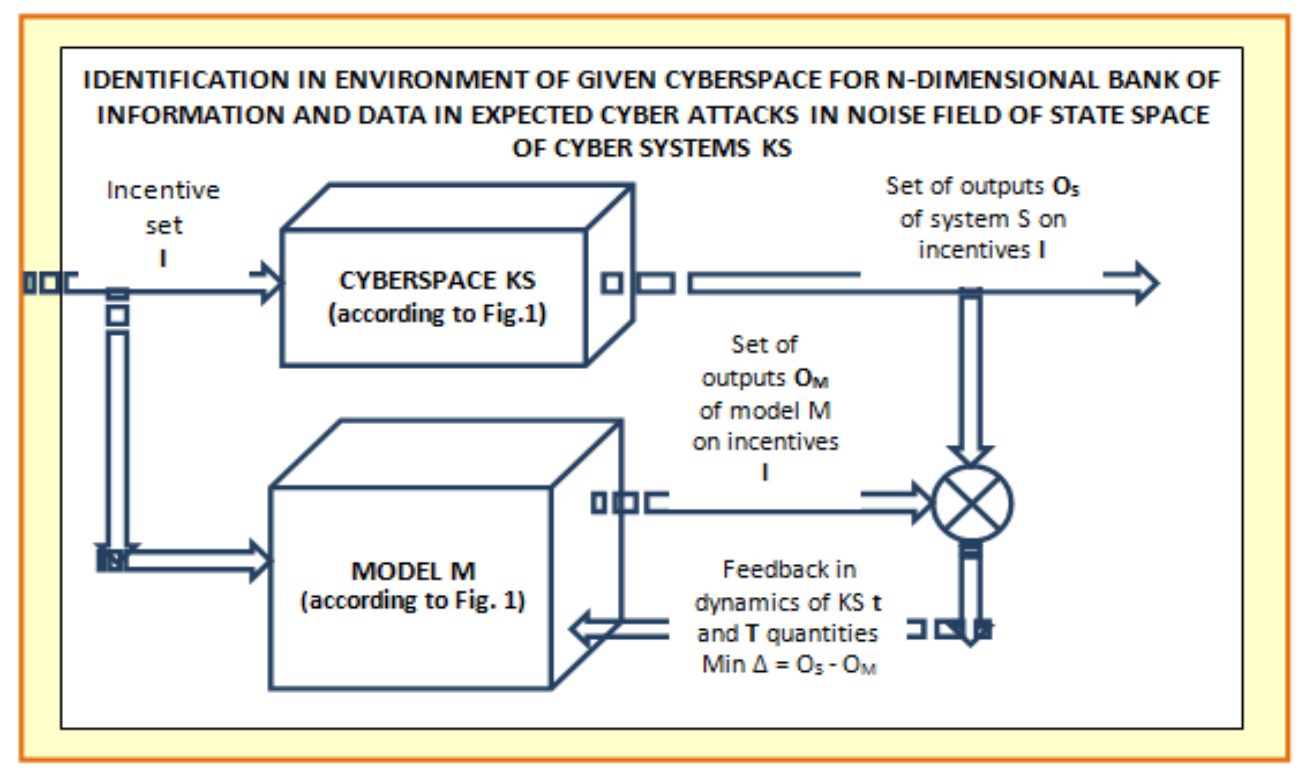

FIGURE 3. The principle of used simulation modelling.

\section{CONCLUSION}

Steps taken at the very beginning of the research focused on the analysis of existing systemically conceived possibilities of cyber attacks' identification. By studying world information resources, we came to conclusion that the core of system integration in this field has to be particularly uniformed and adaptable state space expressed on the basis of the principles defined in theoretical materials of systems and cybernetics.

The decisive moment of the research was the use of cyberspace. This space was expressed as a copy of possible bionic system with "cells" and a possible technical solution of a simple immune system same as in living organisms. 
To make the existence of this cybernetic system happen, it was necessary to discuss an adaptive base security of identification process and diagnostic management of the project's sensitive parts attacking. Also, there was a discussion about an adaptation of modules, for example by partial discharge of program structures (such as in living organisms after a surgery of cell tissues etc.).

The contribution of this research was the design and implementation of the simulator's part for the acquisition of real processes in real environment. The partial solutions that are currently being solved are highly complicated, but solvable.

\section{ACKNOWLEDGMENTS}

The work was performed with financial support of research project NPU I No. MSMT-7778/2014 by the Ministry of Education of the Czech Republic and also by the European Regional Development Fund under the Project CEBIATech No. CZ.1.05/2.1.00/03.0089 and Project No. 1.07/2.3.00/20.0035 for the development of human resources for science and research activities of Tomas Bata University in Zlin.

\section{REFERENCES}

1. M. Barvír, Kybernetika a společnost na prahu XXI. století, Brno: Vysoké učení technické, 2005, ISBN 80-214-3058-3.

2. J. David and F.Gene, Feedback control of dynamic systems, New Jersey: Prenticehall, 2006, ISBN 0130323934.

3. J. Dvořák, E-commerce and its Impact on Customer Strategy. Economics and management. Lithuanian Republic, Riga, 2010, pp. 397-407, ISSN 1822-6515.

4. M. Janková, The System Approach to Management Principles in Cyber space Dynamic of the Information Society, Comparative European Research. SCIEMCEE. London: SCIEMCEE Publishing, 2015, pp. 26-29. ISBN: 978-0-9928772-62.

5. R. Jašek, A. Szmit, and M. Szmit, Usage of Modern Exponential-Smoothing Models in Network Traffic Modelling: prediction, modeling and analysis of complex systems. 1st edition.: Springer International Publishing Switzerland, 2013 , pp. 435-444, ISBN 978-3-319-00541-6.

6. J. Křupka and Š. Špirko, Basics of Technical Cybernetics. Liptovský Mikuláš: Armed Forces Academy of General Milan Rastislav Štefanik, 2008, ISBN 978-80-8040-357-7.

7. J. Křupka and M. Kašparovská, Abeceda tvorby modeli̊ pro MATLAB, Pardubice: Univerzita Pardubice, 2009, ISBN 978-807395-236-5.

8. E. Volná, M. Kotyrba and R. Jarušek, Multiclassifier based on Elliott wave's recognition, Computers and Mathematics with Applications 66 (2), 2013, pp. 213-225. ISSN: 0898-1221. doi: 10.1016/j.camwa.2013.01.012.

9. E. Volná, M. Kotyrba and M. Janošek, Knowledge discovery in dynamic data using neural networks. In Kuinam J. Kim, K. J. (ed.) Information Science and Applications. Lecture Notes in Electrical Engineering (Bookseries), Springer Verlag Berlin Heidelberg, 2015, Volume 339, pp. 575-582. ISSN: 18761100. DOI: 10.1007/978-3-662-46578-3_67.

10. E. Volná and M. Kotyrba, A comparative study to evolutionary algorithms, In Squazzoni, F., Baronio, F., Archetti, C., and Castellani, M. (eds.): Proceedings 28th European Conference on Modelling and Simulation, ECMS 2014, Brescia, Italy, 2014, pp. 340-345. doi: 10.7148/2014. 